\section{Winning the obesity battle}

\section{Daniel S. Blumenthal, MD, MPH}

President, American College of Preventive Medicine and Professor Emeritus, Department of Community Health \& Preventive Medicine, Morehouse School of Medicine, Atlanta, GA

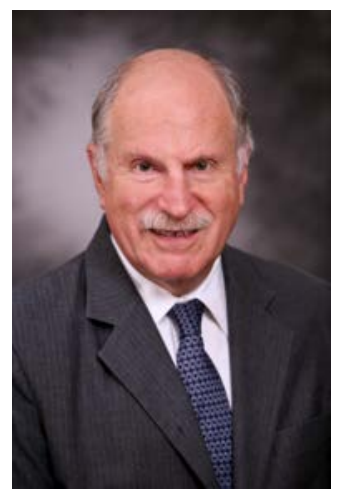

There is no doubt that the United States, and especially Georgia, suffers from an obesity problem. Over a third of U.S. adults are obese (CDC, 2016a), as are about $18 \%$ of children and $21 \%$ of adolescents (CDC, 2016b). Similar percentages in each category are overweight, with a body mass index (BMI) greater than is considered healthy, but not great enough to fall into the obese category.

In Georgia, over 30\% of adults are overweight, a figure that makes us the $19^{\text {th }}$ most obese state in the US (Trust for America's Health, 2016). As recently as 1990, only $10 \%$ of Georgia adults were obese. As in the rest of the nation, Georgia has a marked racial and ethnic disparity in obesity rates: $37.5 \%$ of African American adults are obese, as compared to $27.5 \%$ of white adults and $27.0 \%$ of Latino adults (Trust for America's Health, 2016).

The obesity epidemic, it seems, sneaked up on us. We had gotten quite fat before anybody really noticed. And yet, we should not have been surprised; over the years of fattening, the causes of the epidemic were mounting. Video games, Facebook, and other computer-based recreations were replacing outdoor energy-burning activities for kids. In addition, the growth of cable television, with dozens of channels, meant that there was always something interesting or attractive on TV -- yet another reason to stay inside rather than going out to play.

On the calorie intake side of the equation, the proliferation of fast-food restaurants meant that cheap calories were becoming ever more available. Two types of marketing figured prominently: marketing to children (using clowns and kids' meals featuring toys, for instance); and the "bigger is better” gambit (bigger hamburgers, bigger tacos, and 2 pizzas for the price of one). Health educators and nutritionists tried to tell us to eat healthier diets, but they were hopelessly outgunned: the fast food industry spends over four billion dollars annually on advertising (Philpott T, 2010). Among other problems contributing to the epidemic was that of "food deserts," low-income communities where the only groceries available were junk food sold in convenience stores.

But eventually, public health research scientists began testing community-level strategies for combatting the epidemic, and some of the strategies turned out to have merit. The Guide to Community Preventive Services now recommends four such strategies: behavioral interventions to reduce recreational sedentary screen time among children; worksite programs; and technology-supported multicomponent coaching or counseling interventions, both to reduce weight and to maintain weight loss (The Guide to Community Preventive Services, 2016). The Centers for Disease Control and Prevention lists "Nutrition, Physical Activity, and Obesity" as one of 10 "winnable battles" in public health (CDC, 2016 c). In pursuit of a victory in the battle, the agency has identified 24 strategies, divided into six categories: 1) strategies to promote the availability of affordable healthy food and beverages, 2) strategies to support healthy food and beverage choices, 3) a strategy to encourage breastfeeding, 4) strategies to encourage physical activity or limit sedentary activity among children and youth, 5) strategies to create safe communities that support physical activity, and 6) a strategy to encourage communities to organize for change (Kahn et al, 2009).

There is some evidence that the application of these strategies is making a difference. The publicity focused on the problem, including Michelle Obama's "Let's Move" campaign, may have contributed as well. At least among children, the rate of increase in average BMI seems to have slowed (Wang et al, 2012). But even though McDonald's no longer sells Happy Meals, the factors causing the obesity epidemic are not going away. It is up to public health workers to redouble our efforts in applying evidence-based strategies to overcome the budgetary and other disadvantages that we face. This issue of jGPHA is devoted to addressing the obesity epidemic, and it is making its contribution to the evidence base. It deserves a careful reading, because there are many ideas contained herein that can be applied to our daily work.

Centers for Disease Control and Prevention: Adult Obesity Facts. http://www.cdc.gov/obesity/data/adult.html. Accessed January $18,2016 a$

Centers for Disease Control and Prevention: Childhood Obesity Facts. http://www.cdc.gov/healthyschools/obesity/facts.htm. Accessed January 18, 2016b

Centers for Disease Control and Prevention: Winnable Battles. http://www.cdc.gov/winnablebattles/ Accessed January 18, 2016c.

Kahn LK et al: Recommended Community Strategies and Measurements to Prevent Obesity in the United States. Morb Mort Weekly Report July 24, 2009 / 58(RR07);1-26.

Philpott T: The Fast Food Industry’s $\$ 4.2$ billion marketing blitz. Grist, Nov.10 2010. http://grist.org/article/food-2010-11-09-the-fast-foodindustrys-4-2-billion-marketing-blitz/. Accessed Jan 20, 2016.

The Guide to Community Preventive Services: Obesity Prevention and Control: Interventions in Community

Settings. http://www.thecommunityguide.org/obesity/communitysettings .html. Accessed Jan 18, 2016

The Trust for America's Health and the Robert Wood Johnson Foundation: The State of Obesity. http://stateofobesity.org/states/ga/. Accessed January 18, 2016

Wang Y, Baker JL, Hill JO, and Dietz WH: Controversies Regarding Reported Trends: Has the Obesity Epidemic Leveled Off in the United States? Adv Nutr 3: 751-

752, 2012 http://advances.nutrition.org/content/3/5/751.full Accessed Jan 19, 2016 